\title{
nature
}

\section{Towards the next trade war?}

\section{The trouble brewing on trade between Japan and the United States looks as if it may turn nasty. Both sides are to blame, but the rest of us will be hurt if the worst happens.}

THE good news is that there has not bcen a trade war between the industrialized nations since the ending of the Second World War. The bad news is that the series of disputes bubbling between Japan and the United States over access to each other's' markets in advanced electronics could easily become the open war whose avoidance has maintained the remarkable growth of world trade for the past four decades. More constantly than any other, the succession of governments of the United States has played a crucial part in determining this pattern on increasingly open markets. There is no meaningful dispute about the benefits we have all enjoyed from the liberalization of markets during this long period. Industries that werc once parochially successful have been able to sell to the whole world, enhancing their prosperity and that of those who work for them. What has been happening is the extension of Adam Smith's doctrine of the efficient division of labour to the international economy.

What has cast such a long shadow over the happy prospect that liberalization would continue indefinitely? There must be clues in two sombre developments reported elsewhere in this issue (p. 319). First, by breathing heavily, Mr Malcolm Baldrige, the US Secretary of Commerce, has managed to dissuade Japanese Fujitsu from going forward with its offer to purchase 80 per cent of Fairchild, a US company well-known as a supplier of semiconductor chips to the US Department of Defense, which has been on the block because its parent company, French-registered Schlumberger Limited, has been badly affected by the slump in oil exploration in the past few years. No legal instruments were invoked to secure Fujitsu's retreat, but only the threat that it might be necessary to do so. Second, in a more subtle because more effective development, Japan has arranged that a consortium whose technical expertise is dominated by foreign companics (including the British-registered company Cable and Wireless) sceking a licence to provide overseas telecommunications services for Japan should be merged with a Japanese latecomer to the competition. The significance of that development is that it weakens Japan's case for claiming that companies elsewhere would be more successful at selling to Japan if they were able to manufacture goods of a quality acceptable to discriminating Japanese customers (which remains, in many cases, the plain truth).

The trouble, so far as it afflicts the United States, is that the manufacture of electronic components, and especially of semiconductor chips, has become a symbol of nationhood. In the language of the business schools, rationality would dictate that manufacturers of equipment incorporating microchips should buy their components from the cheapest supplier, reckoning thereby to increase the margins on its finished products. Two unrelated sets of calculations have muddied this simple picture. First, national security: the snag there is that the argument about the folly of allowing one of the tradesmen to the Pentagon to be owned by a foreign company is undermined by the consideration that Japan is among the most dutiful of the allies of the United States, and that there is no pattern of trade that changes more quickly than that in microchips. Second, and emotionally much more immediate, the United States is convinced that it is being taken for a commercial ride by Japan. What else can be made of the deficit on overseas trade, which amounted to no less than $\$ 180$ million last year? The defect in that argument is the miscalculation that the US trade deficit is a sign of foreign (predominantly, but not exclusively, Japanese) exploitation of the United States. Rather, it is the arithmetical consequence of the US budget deficit. How else than by borrowing from overseas could the United States government consistently outspend its revenue from taxes while refraining from printing money? Last August's microchip agreement between the United States and Japan, doomed to failure from the start for its lack of a convincing definition of fair price (marginal and average costs differ remarkably in capital-intensive industries) was in retrospect an attempt to demonstrate that two small integers do not add up to what childhood lore maintains.

Japan is also not free from blame. Naturally, there is no particular reason why Mr Nakasone's government should have decided three years ago that its trade in telecommunications should be thrown open to all-comers. It could just as well have followed, say, West Germany in the conviction that a nation's telephone conversations with others are too important to be run by anything but an oligopoly of the originators of the messages. Unhappily, for Nakasone's government, it did decide that the time had come to open its telecommunications market. To say the least, it now looks bad that it has closed that market by the old-fashioned subterfuge of pretending that consensus, even at pistol-point, is better than flagrant competition, giving comfort to its critics in the process. And has the famous Japanese consumer had a say?

Bystanders to these parallel but non-intersecting lines of argument, most of Western Europe in particular, must ask themselves two separate questions and then try to find an answer. They, like Japan and the United States, are tainted, in their regard for the principles of free trade and the better division of labour, by their practice of doing almost everything they can to ensure that the downside of compliance will hurt others, not them. The result, in Western Europe, is a common market whose members are as much divided from each other by their petty (but sometimes major) trade barriers as they are united by the conviction that Europe matters. Last week's failure by the European Commission to secure the permission of its political masters to fire a warning shot over the bows of price-fixing airline cartels is relevant. If the world's two most prosperous nations are to have a trade war, should the others band together in neutral mutual self-advantage?

The second more difficult question is that of whether the impending trade row between the United States and Japan can be headed off. If the US presidency were stronger, its successes of the past few years could more easily be headed off. If the US Congress were less frequently compelled to run for re-election, the pressure on congressmen would also be less. But to ask for other circumstances in a pre-election year makes nonsensc. The best hope is that the two contenders for the world-title in high technology should call off their contest, and competc for something else instead. Because that will not happen, the ncxt best, but slender, hope is that one or other will recognize the dangers before the fight begins. 